\title{
THE PHILOSOPHY OF HEALTH YEAR
}

\author{
Johan De Beer, Secretary for Health
}

\section{OPSOMMING}

Gesondheidsjaar 1979 is 'n landswye inligtingsprogram, bedink om alle mense van die probleme wat hul gesondheid bedreig bewus te maak, en om hulle te motiveer om positief daarop te reageer. Hierdie probleme verskil natuurlik van gemeenskap tot gemeenskap en gevolglik sal elke sektor van die gemeenskap anders betrokke raak. Geïsoleerde plattelandse gemeenskappe, stadsbewoners, nyweraars en boere ervaar egter gemeenskaplike en unieke gesondheidsvraagstukke. Uit die aard van haar werk is die verpleegster in baie nouer voeling met die verskillende gemeenskappe as enige ander lid van die gesondheidspan. Verpleegsters kan die filosofie van Gesondheidsjaar - gemeenskapsbetrokkenheid — sowel binne as buite die hospitaalopset aansienlik bevorder. Dit is baie belangrik dat die gedagte van Gesondheidsjaar nie tot 1979 beperk word nie, maar dat dit in die toekoms uitgebrei word om die ideaal van 'n gesonder gemeenskap te bereik waarin individue vir hulself sal sorg, hul gesinne en vriende, die gemeenskap en uiteindelik ook die hele volk sal betrek.

A FTER a long planning period, Health Year is now with us and in full swing. It is to be hoped that during the course of the year everyone has been bombarded with reminders of the activities that have contributed to the success of this national venture. Some, if not most of you, must have pondered on the raison d'être on the philosophy behind Health Year.

The choice of 1979 was by no means arbitrary. It is the 60 th anniversary or diamond jubilee of the first Public Health Act passed by Parliament in South Africa. Prior to 1919 the responsibility for the determination of health needs was illdefined and left to the discretion of the three levels of government. It was the devastation caused by the influenza epidemic of 1918 that highlighted the need for adequate health legislation. The emphasis of the Public Health Act, No. 36 of 1919, which established the Department of Health as the central health authority, was on the control of epidemic diseases. The Act of 1919 served as a precursor to several other Health Acts which have formed the basis for the provision of health services to the inhabitants of this country. Although these services have been the means by which many health goals have been attained, the Department of Health has been constantly aware of the need to keep abreast of the limes. During the past decade all the main Acts pertaining to health have been amended. Vigorous atlempts to rationalise all health services in the Republic, at a time when good services existed generally, culminated in the Health Act, No. 63 of 1977. It ushered in a new era, the spirit of which became the main stem of Health Year. Previous legislation had favoured the provision of health services along the lines approved by those in authority, while the new Act of 1977 created the opportunity for community participation in the rendering of a comprehensive health service.

The cost of living affects every one of us. Health services do not escape from this problem and throughout the world authorities deliberate on the distribution of resources to health care. The more wealthy nations appear to pour an endless amount of their wealth into medical care but the result, in terms of a reduced mortality and better health of their populations, is questionable. Of late, economists have attempted to apply the productivity assessment of cost-benefit analysis to health care which, thus measured, has in many cases been found wanting. Some of the instances cited are the efficiency of diagnostic and therapeutic procedures; the efficiency with which they are provided and the unwarranted duplication of services. In practical terms, efficiency is the maximisation of effectiveness with the minimum of resources. Accepting that the energy crisis and the lack of limitless resources will restrict the relative availability of finances for health care, we must plan an alternative to the present state of dependency on expensive medical services. Since it is the community which is eventually responsible for meeting the costs of healtii care, the community must be involved in the allocation of resources by the most efficient method available.

Various medical breakthroughs in both curative and preventive medicine have placed hospital medicine and technology on a pedestal and led to a hospital-based, curative orientation of health services. One result has been the erroneous belief that the more doctors, nurses and hospitals that are available to the community, the better its health will be. Health Year is an opportune time to make the public aware that an infinite number of health professionals, sophisticated facilities and personal medical care cannot create, or make a great contribution 10, health but, at best, merely facilitate a return to health. Likewise, no public health measures or acts of Parliament can themselves make us healthy. In the main, the improvement in human health over the past couple of centuries has not been achieved by the advances of clinical medicine but rather as a result of environmental manipulation and improved nutrition. 
Health and health care cannot be considered in the same manner as other commodities. Unlike education, for example, health care is a commodity delivered to those who are not in normal health, whereas education and most other services are designed for those who conform to a norm. Health cannot be guaranteed by the largest of incomes; a fact which has led to the observation that one's health is one's greatest wealth. Nevertheless, health is often not appreciated as an asset until it is replaced by illness. Health Year was designed to create an awareness of the value of health which should not be squandered lightly. The course for the future should not lie in the pursuit of clinical cures but in maintenance of health by control of our personal behaviour which plays an important role in disease today.

People talk glibly about the State's moral obligation to provide health care as a basic 'human right' but barely mention the individual's responsibility to protect his own health for the benefit of the state. The four fundamental human rights are described as safe drinking water, sufficient food, protection against communicable diseases and access to the means to control fertility. While any State might strive towards this goal. success is entirely dependent on individual and community participation. As many of the 'diseases of civilisation' are largely a result of individuals' adverse behaviour, it behoves all of us to promote our own health by stopping smoking, eating a balanced diet, drinking less alcohol, keeping fit and avoiding the risk of VD or unwanted pregnancy. If each individual does not take steps to protect his own health, is he justified in expecting someone else to bear the brunt of diseases arising from his negligence? Although prevention is more effective and cheaper than cure, it cannot become the sole form of medical care in the future since we have not yet reached a stage when all diseases can be predicted and hence prevented. Thus Health Year was not conceived as a step towards eliminating curative services but as a means to promote the concept of prevention of illness and maintenance of health. Where past medical care has been focussed on the sick person, future health services will pay more attention to the healthy individual.

Health Year is essentially a nation-wide information programme for every member of the population. Participating bodies include all health authorities and health-related associations and institutions. As health is a multi-faceted entity encompassing physical, mental and social well-being, one can readily appreciate what a large number of organisations are involved in the Health Year activities. Apart from promoting the concept of good health and healthy living, Health Year is also designed to provide information about the availability and use of health services. The overall aim is to engender active interest and community participation in health matters. It is envisaged that country-wide cooperation may be achieved by stimulating the interest of the individual who, after securing his own health, will involve his family, friends, community and ultimately the nation.

One may well wonder why there should be communi- ty involvement and a Health Year to promote the concept. The tremendous cost of hospital services has already been mentioned. Not only buildings and consumables contribute to the costs, but also the salaries of the employees required to render the service. In addition, in many parts of the world, including South Africa, there is a shortage of trained manpower, necessitating the investigation of new ways to supply adequate health care to the population. The development of day hospitals and provision of primary health care are but two of many solutions. Another possible course is to encourage self-care; and here we return to the underlying philosophy of Health Year. In recent times the public has shown a desire to be informed about and take part in decision-making in most areas of life, not least of all in health matters. Health Year and the modern, flexible Health Act of 1977 provide for the dispersal of information and the establishment of a comprehensive health service in which the public may take an active part.

The history of mankind has been the history of a continual struggle against death and dearth. Over the past century, environmental progress and medical science have brought under control most of the world's major infectious diseases but in doing so they have left fertile ground for other problems to develop. The population explosion threatens to reduce the standard of living and outstrip medical resources. The prolongation of the average lifespan has in many cases exchanged an earlier death for chronic ill health. Self-inflicted ill health stems either from ignorance or from failure to heed the facts and change one's lifestyle. Self-indulgence and overreliance on medical cures and labour-saving equipment have abetted the escalation of the degenerative disorders. Health Year is the time to cast off harmful, slothful habits for more healthy pursuits. The hankering after the good life of indulgence should be overcome since getting fit and keeping healthy should be sufficient reward for one's sacrifices. Health Year presents each individual with some particular challenge - giving up smoking, losing weight, physical exercise or perhaps learning to relax.

The finance of Health Year is an investment in preventive medicine but remains a small amount compared with the cost of curative services in South Africa. Investment in healthy individuals will produce excellent dividends for the country. All that is expected from any individual is devotion of time and energy to his own health in order to reduce the need for expensive facilities. South Africa takes a leading role in many branches of medicine including that of heart surgery. This is, however, in some ways a dubious honour since it also reflects an extensive need for hearl surgery. If everyone would stop smoking, eat wisely, take exercise and get prompt treatment for hypertension, South Africans would have much less need of such a costly service.

Although it was decided that 1979 was to be the International Year of the Child, the Department of Health had already decided to celebrate Health Year to embrace people of all ages in our country. Health Year is for young and old alike. Nevertheless, children have 
been the focus of a significant proportion of the Health Year programmes. Schools and youth organisations have been urged to place a greater emphasis on health projects and community involvement. Art competitions have been organised to make children more aware of health and the means by which it can be improved or maintained. The philosophy of such activities is that people learn more by participation than from instruction. Information on child nutrition - from breastfeeding to tuckshops - has been particularly sought after in brochure form and group discussions. Health Year is utilizing the mother-child bond in trying to fulfil the World Health Day slogan, 'a healthy child, a sure future'. The philosophies of Health Year and the International Year of the Child have been married in the preparation of a book, 'Keep your child healthy', which has been prepared by the Department of Health and the South African Council for Child and Family Welfare.

The many health-orientated welfare services whose activities intersect in the field of medicine should use Health Year as an opportunity to liaise with one another and co-ordinate their efforts to give comprehensive care to the community. There are several areas where such an interdisciplinary approach to health care and welfare would be valuable. These include the area of primary health care and, in particular, the provision of care to the older members of the community. As far as is possible, community participation in caring for those unable to look after themselves is preferable to care in expensive, impersonal state institutions. This philosophy applies to all groups of dependents be they mentally retarded, cripples or elderly and infirm. Health Year should inspire this spirit of concern about the less fortunate.
Elderly should not be considered as synonymous with dependent. Many senior citizens remain self-sufficient and play an important part not only in maintaining their own health, but also in caring for others. The elderly are a valuable source of health educators for their peers and families. When a mother works it is often the grandmother who minds the children and thus granny can to a large extent influence a child's health. Older people are therefore just as important a target group for health information as the younger generation. Health Year has not neglected those senior citizens who need advice on facilities or services to improve their lives. A book on the health care of the elderly has been published to assist those who are caring for old people within the community.

Health Year was conceived as a means to interest people from all walks of life in the problems threatening our health; and to motivate them to rectify the situation. Naturally these problems vary from community to community so each sector of the population may be concerned in different ways. Isolated rural communities, city-dwellers, industrialists and farmers all have mutual and individual health challenges. By the very nature of her work a nurse comes into closer contact with the various communities than any other health professional. Within and without the hospital setting, nurses can give substantial support to the philosophy behind Health Year - community involement. Perhaps the most important point about the philosophy of Health Year is that it should not be confined to 1979 but must extend into the future to attain the Utopian goal of a healthy community in which individuals care for themselves and their neighbours. 